State of Alaska

Department of Natural Resources

DIVISION OF MLNES AND MTNERALS

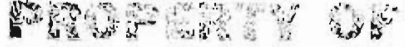 \\ Hed \\ STA \\ DIVISION OF \\ GEOLOGICAL SURVEY}

P. O. Box 1391

Juneau, Aleska

MINES AND PETROLEUM BULLETIN

February, 1962

Vol. $\mathrm{X}$

No. 2

MINING ACTIVITIES

Southeast District - Governor William A. Egan reports a possibility that the production ellocation for the uranium property at Boken Mountain on Prince of Wales Island may be increased by the AFC. Bay West, Inc. had announced its hopes to resume mining early this spring, but had also advised the Govemor that without a larger allocation, it might not be able to do so. The Governor requested a larger allocation from the AEC. This request was rejected, but was renewed by the Governor and word has now been recelved thet the AEC is reviewing a 1958 reserves report, and that an increase in the allocation may follow.

John C. Williams of Williams Hydraulics, Inc., Oakland, California, announced plens to prospect and oredge the bottom of Stephens Passage south of Grand Island for placer gold. The area covers elght square miles of submerged lands, and depths vary from 520 to 810 feet. If systematic prospecting reveals gold in paying quantities, Mr. Williams' State prospecting permit must be converted to a mining lease under State regulations before dredging may comence. Dredging would be performed with a special hydreulicly-operated clam-type deepwater dreage invented by Williams prior to the war for this particular project. Preliminary sampling in 1933 indicated values and started Williang on this venture which wes interrupted by the war and in which he reports to have invested $\$ 1$ mililion to date.

OII NEWS

During the first month of 1962 the Petroleum Branch of the Division of Mines and Minerals approved two applications for permits to drili, both for gas wells, in the Swanson River Dil Field. The wells and their respective locations are as follows: Soldotria Creek Unit 243-8, Sec $8 \mathrm{TTN}, \mathrm{R}$, approx: 2120'N \& 1070'W of SE cor of Sec 8, El. 157' gr; Swanson R1yer Unit 221-33, Sec 33, T8N,R9W, approx: 1980 'E \& 660'S of NW cor of Sec 33, E1. 160' $\pm \mathrm{gr}$.

Approvals for the same period in 1961 totalled four, thus showing a $50 \%$ decrease in drilling thus far in 1962. This decrease is caused by the fact that the Swanson River Field is practically drilled out, causing a halt in applications for development drilling. Wiben another discovery is made, development drilling will again swell the total driling activity. The Petroleum Branch estimates that a possible 25 exploratory (wilacat) wells will be drilled or drilling in Alaska 'by the close of 1962.

Drilling Activity - Jenuary 30, 1962

Operator

SOCAL

SOCAL

Pan American

Pan American

Superior

SOCAL
We1I. Name \& No.

$\operatorname{SCU} 34-16$

Chaix Hilis Unit 1-A

Stedatna Creek - State I

Wost Foreland 1

Chuit - State 1

SCU 32-5
Status

T.D. 6,295', repairing location Drilling \& 8,570'

Drilling

Drilling

Drilling

Drilling @e. $7,400^{\prime} \cdot$ 
Completion - January 30, 1962

operator

Richfield

SOCAL

SOCAL

SOCAL
We1l Name \& No.

Bering River Unit 2

SRU $21-22$

SCU 34-8

SCU 21-3
Status

TD 6019', P\&A

TD 11,012', POW

TD $11,175^{\prime}$, POW

TD $11,100^{\circ}$, POW

Production, Swanson River Field

\begin{tabular}{|c|c|c|c|c|}
\hline. & $\begin{array}{l}\text { Producing } \\
\text { Welis }\end{array}$ & $\begin{array}{c}012 \\
\text { (barrels) }\end{array}$ & $\begin{array}{c}\text { Nater } \\
\text { (barrels) } \\
\end{array}$ & $\begin{array}{c}\text { Gas } \\
(\mathrm{MCF}) \\
\end{array}$ \\
\hline $\begin{array}{l}\text { December, } 1961 \\
\text { Cumulative to }\end{array}$ & $\quad 45$ & 797,422 & 18,179 & 148,927 \\
\hline January 1, 1962 & & $7,116,844$ & 203,628 & $1,391,920$ \\
\hline Production, Kenai & eld & & & \\
\hline $\begin{array}{l}\text { December, } 1961 \\
\text { Cumulative to }\end{array}$ & 3 & 0 & 0 & 91,060 \\
\hline January 1, 1962 & & 0 & 0 & 231,294 \\
\hline
\end{tabular}

Standard Announces Construction of Refinery - Standerd 011 Company of Californie has announced that a contract for the construction of the 20,000 barrel per day refinery on the Kenal Peninsula has been awarded to the Ralph M. Parsons Company of Los Angeles, California. The refinery will be constructed on a 481 -acre tract adjacent to the marlne terminus of the Kenai pipeline. Work is expected to commence soon after spring break-up with completion scheduled early in 1963. Initial refined production will be heating oil, diesel fuel, jet fuel and light Puel oil. Production wlll be expanded to gasoline at a later date.

Release of Records - Pursuant to Section 2008.I of the Alaska 011 and Gas Conservation Regulations, well records of the following well will be released publicly February 3, 1962: Swanson River Unit 32-22, Standard 013 Company of California, operator.

Interior Department Petitioned to Open South Half of Kenal Moose Range to Oil and Gas Leas-; ing - Seven lease applicants, who had a total of 28 applications in the closed, southers portion of the Kenei Moose Range on the Kenai Peainsula rejected last year, filed suits in Federal District Court on January 26, 1962 in which they asked the Court to require that the Secretary of the Interior approve their applications originaliy filed in 1954 and 1955. The applications were rejected last year on the ground that oil and gas exploration would be detrimental to the moose in the two million acre range. The applicants contend in their identical suits that the Interior Department has no legal authority to make such closures, that rejection of the applications after the long delay was unfaix and inequitable, that oi.l and gas exploration actually would benefit the area and Alaska by development of natural resources with attendant revenue from fees and royalties, and that Congress intended that such lands should have multiple use provided fish and wilolife are protected.

Duktoth River Unit Agreement Fxtended - The USGS has extended the drilling comitments of the Duktoth River Unit Agreement, Richfield Oil Corporation, operator, to February 8, 1963.

Swan Lake Unit Agreement Extended - The USGS has extended the driling comitments of the Swan lake Unit Agreement, Standard 0 il Company of California, operator, to March 25, 1963. 
We are informed that preluninaxy studies made for the corps of Engineers by the Development and Besoures Corporation indicate that a market will exist for the 5 million kilowatis of lowicost powe which can be produced at Rampart Dam on the Yukon River: The preliminary report indicates that most of the. cheap power could be sold to electroprocess industries", particularly those using electrometallurgical processes for the treatment of both domestic and imported ores. In a letter of transmittal, the New York firm (of which David E. Lilienthal and Gordon R. Clapp are the principal officers) states "A decision made soon to move ahead: with the Rempart project will, in the decades to, come, prove to have been nationally prudent: and" wise:"

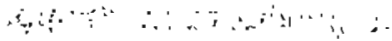

Because. market for the power would largely be deperident on the establishment of electrometallurgical industries, the project would have a tremendous impact on the mineral industry of Alaska. Therefore, a decision to move ahead should include firm plans for the systematic exploration, evaluation, and development of the mineral production potential of the large region in and adjacent to the proposed reservoir. Federal and/or state agencles should conduct a systematic program of mineral finvestigations by modern methods such as aerial geologic and gegphysical survey followed by appropriate surface and subsurface exploration of favorable areas as determined by the preliminary work.

It is our understanding that the Corps of Engineers has authorized reconnalssance of the reservoir area and immediately adjacent territory for the purpose of detexmining the nature and scope of such additional investigation as may be justified. This work should be extended, as plans for the dam progress, in surficient time to ascertain whether any conmercial mineral deposits might exist that could be salvaged before flooding, and whether deposits night exist adjacent to the future 10,800-square-mile lake that would be of value because of the resulting improved transportation or because of the developed low-cost power.

\section{ANNUAL REPORTS}

The Annual Report of the Division of Lands is now available frae of charge at 3446 th Avenue, Anchorage. Because of a different printing arrangement, the DMeM Annul Report for the Year 1961 cannot be made available for another month. It will be sent free of charge irom our office at $B$ ox 1391 , Juneau, as soon as it is received from the printer.

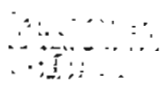

MINING RECORDER CHANGE

ifje and McCartky Recording. Districts has been changed -from Copper Center to Glennallen.

\section{PROPOSED ROAD STUDY}

S.J.: Resólution 137 calling for a study by the U.S. Secretary of Comerce relative to a highwey conotruction program for Alaska was introduced by Senator Gruenjing iest fal1. It would require a report to Congress which would include. (1) an analysis of the adequacy of the:present Federal-aid highwey program in Alaska, (2) specific recomendetions as to construction of roads through undeveloped areas and connections. With Canadian roads, and (3) a program for implementing the recommendations. If passed, $\$ 800,000$ would be required for making the study and report.

WYOMTNG BY-PRODUCT PLANT

The Wall. Street Journal reports that Pacific Power and Light Company is planning a $\$ 300,000$ pilot chemical-process plant In Hyoting to explore new weys to produce coal byproducts subituminous coal. This is in conjunotion. with the company's construction

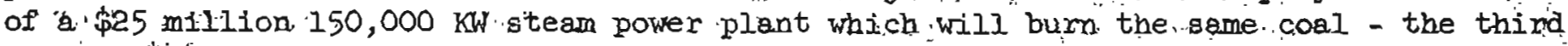


power unit at that location near Glenrock. The pilot plant will use a new method of extracting liquid and solid coal by-products, and possible resulting products will Include coke (used in electro omelting) and active carbon (used for clearing municipal water supplies for domestic consumption). Wyoming has tremendous awounts of subbituminous coel, and has been making all-out efforts for several years to have this coal put into greater production.

$\underline{\operatorname{COT} D}$

Gold production in the state fell about $33 \%$ from 1960 to 1961 , and now ranks fourth on the mineral production list instead of holding the esteemed mmber one position it held for so many years. The Bureau of Mines has estimated that nationel gold production dropped $9 \%$ to a value of $\$ 53$ million, the lowest level since 1884. During the year, the U.S. gold loss was estimated at a little less than $\$ 900$ million, and the nation's stockpile was valued at $\$ 16.890$ b1llion.

\section{ATE}

The SIxth AIME Mining, Minerals, and Petroleum Conference will be April 26 and 27 in Anchorage. Chalrman - Mr. C.E. Smith, Union OSI Company of Celifornte; Program Chairman Mr. William C. Blshop, Richfield Oll Corporation; Petroleum Program Chalman - Mr. C.V. Chatterton, Stendard O1l Company of Californta; Mining Program Chasman - Mr. Cole B. Mafar? land, Evan Jones Coal Company; Geology Program Chalrman - Dr. Ruth A.M. Schm1dt, U.S. Geological Survey, Arrangements Chairmen - Mr. R.S.RIchard,, Rellable Services, Inc.; PublicIty Chatrman - Mr. R.V. Murphy, Alaska Division of Mines and Minerals.

\section{IEOTSLATURE}

The Second Session of the Second Stete Leglelature has convened. Inasmuch as the Division of Maes and Minerels is required to collect and diseminate all official information relative to the mineral resources, mines and mining projects of the state, wo will endeavor to present a resume of bills Introduced that directly affect the mineral industry and miners. If owr readers desire more information on this type of legislation, please feel free to write.

\section{ETCEIIBRA}

Recent USGS publications are: Bulletin 1108-A, Ceology of the Nount KeKinley Quadrangle, Alaska, by Reed, Jr. 1961 and Bulletin 1090, Iron and Copper Deposits of Kesaan Pentnsula, Frince of Wales Island, Southeastern Alaska, by L. A. Warren, Igol. These are avallable at the Government Printing OfFlce, Hasbington, D.C., and are also on file at the DIvision of Hines and Minerals' offices.

The following comes from the December issue of Western Miner and Oil Review, The Discovery Post: "A random observation.. . Is our mining exploration too mich 'up in the afr?' There is growing evidence that most of the mineral discoveries being made in the rugged, mountainous terrain of the Pacific Northwest are those by prospectors working on foot. In number of instances, these prospectors report they have made their discoverles in areas that had previously been surveyed by exploration crews. Is it possible that the ease and ipeed of moving about in a bellcopter is having an adverse effect on scone of our minerel explorers? Evidence shows that during the past year, five discoveries of some importance Were made by individuals who had plenty of time to carefully search the areas in which they were working. The helicopter is of tremendous value in servicing parties in the field, but 1.t would appear that its application and usefuiness mist be carefully considered. It is Interesting to note that one of the most important 'P1nds,' that is, the silver-Iead discovery at the headwaters of the Liard River, was made by veteran prospector Mels Hals, who worked with three pack dogs carrytng 35 pounds apiece and one Indian packer. Among other discoveries during the past year are the following: snother outcropping of scheelite, tung- 
sten ore, on the holdings of Canada Tungsten Corporation by prospector Colin Wilson; asbestos at the headwaters of the Tak River by Steve Papp; copper on the eastern contact of the Coast Range batholith by Bob Zelinski; and copper in the Dease Lake area by Larry Callison and partner." We need men in the field; some of these "finds" are at our back door.

"News and Views" section of the November issue of Mining Congress Journel tells thit General Electric Company, working in cooperation with Montana School of Mines under a research grant from the Anaconda Company, reveals that a nonexplosive process for breaking rock with radio-frequency electric power has been achleved. The energy of the radiofrequency creates sufficient heat or stress to split the rock. The process is dustless, fast, and more economical than explosives.

The November issue of Mining World, "What's Going on in Mining" reports a new placer drill which uses pile driver action and double casing. An aix pump forces water down through the outer casing, lifting the core up through the center pipe and out a hose into the washing plant. The machine averaged $1-1 / 2$ feet per minute on ground of Vermillion Gold, Inc., Senders County, Montana.

The January 18 issue of E\&MJ Metal and Mineral Markets reports that the International Tin Council, in London, last week raised the price levels of its currently empty Buffer Pool after obvious pressure Prom Bolivia. Our Administration wants to sell the 50,000 tons of stockpile tin in order to keep the price of tin from going too high. The Bolivians and some members of Congress don't want to see such a large quantity of tin released because of the : depressing affect on world tin prices. (If these people are able to convince Congress that it would be harmful to release the ting. It is assumed that the price will rise to $\$ 1.25$ or $\$ 1.30$ per, pound).

Reprints of two Mining Engineering magazine articles are avallable at the DMRM Juneau office. These are "Geology añ Ore Depostts of Alaska" by Gordon Herreld, DMkM Mining Geologist, and "Alaska's New Mining Law for State Lands" by James A. Williams, DMRM Director. These are free on request from the Division of Mines and Minerals., Box 1391, Junequ.

E. AIND M. J. METAL MARKET PRICES

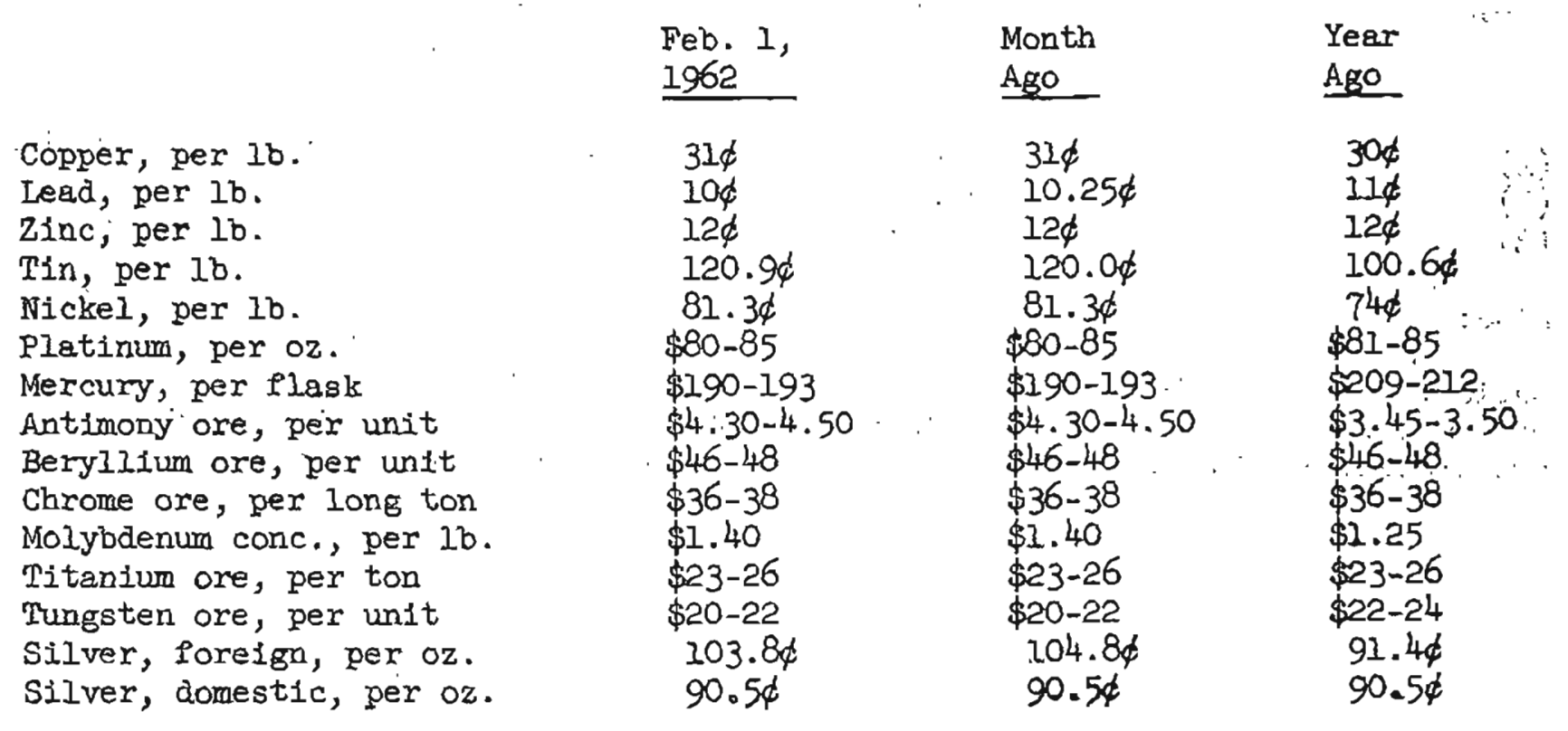


MTNERAL PRODUCTION IN ALASKA

Quantity $\begin{gathered}1960 \\ \text { Velue } \\ \text { (Thousands) Quantity } \\ \text { (Thouluends) }\end{gathered}$

\begin{tabular}{|c|c|c|c|c|}
\hline Clay-_. & 1,150 & 10 & (3) & - \\
\hline Coal, bltuminous--..-thousand short tons & 712 & 6,318 & 750 & 6,653 \\
\hline Copper (2) & 41 & 27 & (3) & - \\
\hline Gold (2) - & 168 & 5,887 & 114 & 3,973 \\
\hline Mercury-1. & 4,459 & 940 & 4,350 & 859 \\
\hline Natural Gas-....--nillion cubic feet & 246 & 30 & 568 & 151 \\
\hline Petroleum, crude--.--thouband barrels & 559 & 1,230 & 6,326 & 17,666 \\
\hline Sand and Gravel-------thousand short tons & 6,013 & 5,483 & 5,750 & 5,200 \\
\hline Silver (2) - . . - thousand troy ounces & 26 & 24 & 16 & 14 \\
\hline Stone-n.thousand short tons & 275 & 852 & 300 & 900 \\
\hline Undistrlbuted (3) & - & 1,061 & - & 1,150 \\
\hline - - & - & 21,862 & - & 36,566 \\
\hline
\end{tabular}

(1) All figures for 1961 are prelintary (except petroleum) and subject to revision.

(2) Recoverable content of ores, etc.

(3) Undigtributed includes gem stones, platinum group metals, uranium ore, cley and copper.

Note: Above statistics prepared under a cooperative agreement for the collection of mineral data between the Bureau of Mines, United States Dopartament of the Interior, and the Division of Mines and Minerals, Department of Natural Resources, State of Alaska. Flgures for cosl, petroleum, natural ges, and undistributed comodities are presented on authority of the Division of Mines and Minerals only. 